\title{
Indonesian EFL Students' Perceptions on the Implementation of Flipped Classroom Model
}

\author{
Rida Afrilyasanti \\ Sekolah Menengah Atas (Senior High School) Negeri 8 at Malang, Indonesia \\ Bambang Yudi Cahyono \\ Universitas Negeri Malang, Indonesia \\ Utari Praba Astuti \\ Universitas Negeri Malang, Indonesia
}

\begin{abstract}
The flipped classroom model has gained popularity in education recently. In this model of learning, the students learn materials (e.g., by watching lectures through video) at home, and then they learn more actively in the school classroom. Although flipped classroom model has been popular, the implementation of flipped classroom in an English as a Foreign Language (EFL) context has not been widely published. This article reports results of research examining students' perceptions on the implementation of the flipped classroom model. It involved 30 senior high school students who joined a writing class using flippled classroom model. Data were collected by using questionnaires, immediate interview and observations. The results of the research showed that the students found the activities applied in the flipped classroom model helped them write better. The videos they watched as well as teacher and peer feedback in their writing process improved their writing ability. This study also presented some caveats for teachers when they intend to flip the class.
\end{abstract}

Index Terms—flipped classroom model, EFL students' perception, writing attitudes

\section{INTRODUCTION}

Due to the needs to facilitate $21^{\text {st }}$ century learning in which technology becomes the core educational tool, flipped classroom model is increasing in its popularity (Brinkley, 2012). In the $21^{\text {st }}$ century learning students tend to study by searching the knowledge from various sources, particularly the Internet. Along the lines of the $21^{\text {st }}$ leaners' characteristics (e.g., critical thinkers and technologically literate learners) and what is considered as a current teaching trend among non-English as a Foreign Language (EFL) context, flipped classroom has been considered effective to facilitate $21^{\text {st }}$ century learning. In a flipped classroom, technology is used to extend content delivery beyond the scheduled class. It incorporates $60 \%$ in-class learning and $40 \%$ online self-learning (conducted at home). Students' selflearning is purposively done to introduce new materials through video lectures and online readings. Furthermore, the self-learning is completed prior to the in-class learning. Meanwhile, the in-class time is used for assimilating knowledge through discussions, tasks, and group works. Therefore, students have more opportunities to interact with their teacher as well as peers. The flipped classroom model replaces teacher-centered teaching to an active learning engagement where the students-centered takes place.

There have been an overwhelming number of studies revealing the effectiveness of the flipped classroom model (e.g., Cole \& Kritzer 2009; Demski, 2013; Gannod, Burge, \& Helmick, 2008; Lage, Platt, \& Treglia, 2000; Slezak, 2014). In Indonesian context, however, only few studies have been conducted on the implementation of the flipped classroom model (e.g., Agustina, 2015; Murtiyasa, Esti, \& Ulfa, 2015; Syafitri, 2014a, 2014b). Murtiyasa et al.'s (2015) study is concerned with Mathematics teaching. Meanwhile, Agustina's (2015) study investigated the effectiveness of the flipped classroom model in teaching story telling and Syafitri's (2014a, 2014b) work examined the effectiveness of the teaching of reading using flipped model. Those studies focused on the effectiveness of the implementation of the flipped classroom model. However, studies on the students' perceptions toward the implementation of the flipped classroom have not been conducted.

In Indonesia, the flipped classroom model is considered as a new teaching model. It is, then, crucial to identify how students feel about and perceive a new teaching model used because students' own judgments on what they were experiencing enable them to recognize the ease of use and perceived of the benefits. As result, there will be a change in their attitudes, which will affect their willingness to study using that model. Therefore, this study focuses on the use of the flipped classroom model in an EFL writing class by investigating students' perceptions toward the use of the flipped classroom model. 
The flipped classroom model refers to a form of teaching and learning process, in which students attend not only for in-class activities but they also manage their online self-learning. By combining the two classes, at home, the students can learn by themselves, and at school, they can be assisted by their teacher and can collaborate with their peers. With regard to writing activities in particular, the regular classes tend to be silent. All students listen to their teacher's explanation on the writing materials. It is then continued by a silent period of writing process. In contrast, in the flipped classroom model, students watch video lectures and learn other materials at home, and then they actively participate in in-class learning (Arnold-Garza, 2014; Herreid \& Schiller, 2013; Snowden, 2012).

A further explanation about the flipped classroom model is given by Bishop and Verleger (2013). They describe the flipped classroom model as an educational technique consisting of two parts: interactive group learning activities inside the classroom, and direct computer-based individual instruction outside the classroom. For the computer-based instruction in a flipped teaching strategy, videos or readings are used. Furthermore, to make sure that students have watched the videos or completed the reading at home, students are required to respond to reading questions as well as quizzes to report their learning progress (Houston, 2012).

According to constructivist learning theory, students learn much by doing, discovering, exploring, and trying out new ideas (Clarke, 2008). Therefore, the best way to test a teaching model is by studying the students' learning. The students must firstly experience the model, then describe their perceptions of the implementation of the teaching model. In proportion to that theory, a previous study which revealed the effectiveness of the implementation of the flipped classroom model in the teaching of EFL writing has been done (Afrilyasanti, Cahyono, \& Astuti, 2016). In the aforementioned study conducted by Afrilyasanti et al. (2016), the students have experienced the teaching of writing using the flipped classroom model. Hence, in conjunction to the students' learning experience in a flipped class, a study revealing on their perceptions toward the implementation of the flipped classroom model is conducted.

Studies investigating students' perception on the implementation of the flipped classroom model generally show positive reports. A study conducted by Herreid and Schiller (2013) for example, indicates that students have a positive association with flipped instruction. Similarly, Ruddick (2012) assuredly adds that students perceived the flipped instruction as a better or more efficient method of teaching. It also improves students' behavior (Chester, Buntine, Hammond, \& Atkinson, 2011).

Probing more on the activities in the flipped classroom model, Grami (2012) and Vurdien (2011) confidently disclose that students showed positive attitudes towards peer feedback. The students enjoy commenting and receiving comments in both, in-class and online class. Additionally, students' positive perception on the activities within the flipped classroom model has been well documented by Musib (2014) and Roach (2014). The students admitted that learning using the flipped classroom model enabled them to have more time to do activities in the classroom.

Conversely, there are some mismatches as well as negative perceptions about the implementation of the flipped classroom model. For instance, a study conducted by Bishop and Verleger (2013) find that students tend to prefer inperson lectures to video lectures, but at the same time, they prefer interactive classroom activities to lectures. Parallel to the aforementioned study, Webb, Doman, and Pusey (2014) also come up with a mismatch perception from the students toward the implementation of the flipped classroom model. The students perceive the implementation of the flipped classroom model positively, however, several drawbacks were also noted. However, the students were not satisfied with the teacher's roles within their flipped class.

In order to address the gap identified in the introduction and literature review, this study purposes to explore the students' perceptions toward the implementation of the flipped classroom model. The research questions are formulated as follows:

1. How do students perceive the meaningfulness of writing activities employed in the flipped classroom model?

2. How do students perceive their writing competence after following the flipped classroom model?

\section{RESEARCH METHOD}

The data for this study were collected from 30 senior high school students who took writing class conducted by using the flipped classroom model. The students were required not only to join the in-class activities, but also to get involved in online self-learning activities by watching video lectures and reading online materials. As the aim of the study was to investigate how students perceive the implementation of flipped classroom model for their learning of writing, the students were given a questionnaire eliciting their perception toward the implementation of the flipped classroom model This is because it is important for the students to make their own judgments of what they experienced from the flipped classroom model.

The questionnaire was developed to investigate the students' perception on the implementation of the flipped classroom model by using Likert-scale response choices (Bertram, 2007; Johns, 2010; Vagias, 2006). A 5-point Likert scale that ranges from "strongly agree" to "strongly disagree" was applied. Each of the scales has a different value, namely 5 for "strongly agree," 4 for "agree," 3 for "neither agree nor disagree," 2 for "disagree," and 1 for "strongly disagree." However, the questionnaire distributed to the students used the reversed order of the values. In order to answer the research questions, 10 questionnaire items were included and the items were based on Yujing's (2015) questionnaire items with some modification. Yujing's questionnaire items were grouped into three aspects which are meaningfulness, impacts, and competence. However, for this research only two aspects were used: meaningfulness of 
the writing activities (Items 1-5) and writing competence (Items 6-10). The questionnaire for this research is shown in the Appendix.

Subsequent to the questionnaire, an immediate interview was also conducted in order to clarify the students' answer toward the results of their questionnaire. It is important in helping researchers clarify and validate the conclusions about the data in the study. Furthermore, the interview is vital for uncovering the students' own statements beyond the unyielding statements given in the questionnaire, the reasons for agreeing or disagreeing the certain statements, and students' explanation toward their conflicting choices. The interview was unguided; there was no set list of questions prepared. It was immediately given subsequent to the questionnaire based on the students' answer to the questionnaire.

In order to enrich the data, an observation toward the students' attitudes during the implementation of the flipped classroom model was also done. The observation focused on the students' participations within in-class and online selflearning activities. Students' participation within their in-class activities was observed directly from their willingness to join the discussion, work collaboratively with others, and finish the tasks given. Meanwhile, students' participation within their online self-learning activities was observed from the report on the students' activity completion as well as activeness in online discussion.

In the presentation of the results of the study, the results of the interview as well as observation will be mentioned necessarily along with the result of analysis of the relevant questionnaire items.

\section{RESULTS}

The results of the research are presented on the basis of the two research questions. The first research question concerned with the students' perception on the meaningfulness of the implementation of the flipped classroom model, while the second one dealt with the students' perception of the writing competence as the result of their participation in the flipped classroom model.

\section{A. Meaningfulness}

The data about the students' perceptions on the meaningfulness of the implementation of the flipped classroom model were mainly obtained from the results of the students' questionnaire after the implementation of the flipped classroom model. There were five statements used as the pointers to examine students' perception on the meaningfulness of the flipped classroom model. Those five statements pinpoint students' perceptions about whether or not the activities employed in the flipped classroom model were beneficial for their learning of writing. The results of the students' responses on the questionnaires given are presented in the Table 1.

TABLE 1

STUDENTS' PERCEPTION ON THE MEANINGFULNESS OF FLIPPED CLASSROOM MODEL

\begin{tabular}{|c|c|c|c|c|}
\hline No & Questionnaire Items & Total value & $\mathrm{N}$ & Average \\
\hline 1 & The work I do for English writing class is valuable to me. & 120 & 30 & 4.00 \\
\hline 2 & The work I do in English writing class is a waste of time & 62 & 30 & 2.07 \\
\hline 3 & The activities during the writing class improve my understanding of the key concept & 117 & 30 & 3.90 \\
\hline 4 & Viewing video lectures and read the materials before class prepare me for the class activity & 102 & 30 & 3.40 \\
\hline 5 & $\begin{array}{l}\text { I do not see any significance to view the lecture and read the materials before class, so I do } \\
\text { not although I am supposed to }\end{array}$ & 68 & 30 & 2.27 \\
\hline
\end{tabular}

As depicted in Table 1, it can be explained that for the first statement, the students agreed that the work they did for English writing class was valuable for them. The students' response to the activities in flipped classroom model is generally positive. The results of the observation confirmed that the students were actively engaged within in-class activities.

For the second statement, the students disagreed that the work they did in English writing class is a waste of time. When an immediate interview was done, however, it was surprising to find out a conflicting answer from a male student in the class. He said, "I did not have any time to watch the video." He did not see any significance to finish the work that he was supposed to do. This certainly challenged teachers to creatively find engaging activities which encourage students' positive responses toward the implementation.

For the third statement, it was found out that the students agreed that the activities during the writing class improved their understanding of the key concept. The students felt that classroom discussions as well as collaborative works within the in-class learning helped them to understand the materials better. The students considered the writing class, which is meant in the third statement, as the in-class learning. Meanwhile, the writing class here is meant to be the flipped class. Therefore, the result for the third statement was in contrast to the result of an immediate interview dealing with the second statement. As it was confirmed by the results of the immediate interview as well as the observation, not all students did the whole activities employed in their flipped classes. Yet, from the observation it was revealed that the students who industriously did the whole activities in both, in-class and online self-learning activities, earned better score than those who were not actively involved in the whole activities within in-class and online self-learning activities (See Afrilyasanti et al., 2016 for the results of the students' learning achievement in the form of score improvement). It was indicated that the students who conducted self-learning by watching the video lectures prior to the in-class writing 
activities essentially improved their understanding of the key concept compare to those who did not watch the video lectures.

Furthermore, students' responses to the fourth statement revealed that they neither agreed nor disagreed that viewing video lectures and reading the materials in online self-learning prepared them for the in-class activities. The results of the observation on the online self-learning activities showed that some students did not watch the video. When the students were asked for their reasons for not watching the videos, they admitted that they did not fully appreciate the importance of watching. Besides, it was discovered that they would wait for the teacher's short explanation prior to the writing task in their in-class activities.

At last, students' responses to the fifth showed disagreement. This is in contrast to their response toward the fourth statement. They admitted the significance of viewing the video lectures yet, in fact, not all of the students watched the video.

In order to enrich the results of the questionnaire, immediate interview was then conducted. From the interview, it was found out that there were some problems, which included technical problems dealing with the facilities, access to the Internet, and excessive learning load. Some of the responses regarding the problems are presented as follows (with the original expressions in Indonesian):

- Saving the Internet quota (Bagaimana menghemat quota Internet)

- In the class session, the teacher will explain the material again (Di kelas Guru akan menjelaskan lagi materinya.)

- My data packet is not sufficient (Paket data saya tidak mencukupi.)

- There are so many things to do. Besides, I still have to finish more homework from other teachers (Terlalu banyak tugas; Belum lagi pekerjaan rumah dari guru-guru lain.)

Thus, the analysis of the students' responses revealed that they have positive perceptions toward the meaningfulness of the implementation of the flipped classroom model. However, students had disagreement on the meaningfulness of watching the video lectures as part of the online self-learning.

\section{B. Competence}

The other five statements of the questionnaire given to the students were about the students' perceptions on their writing competence as the result of the implementation of the flipped classroom model. The results of the students' responses are presented in Table 2.

TABLE 2

STUDENTS' PERCEPTION ON THEIR WRITING COMPETENCE IN THE FLIPPED CLASSROOM MODEL

\begin{tabular}{|c|c|c|c|c|}
\hline No & Questionnaire Items & Total value & $\mathrm{N}$ & Average \\
\hline 6 & I can do well in my English writing class. & 120 & 30 & 4.00 \\
\hline 7 & I am confident about my ability to address the topic (narrative text) on the final exam. & 62 & 30 & 2.07 \\
\hline 8 & Peers' editing and teacher's feedback help me to improve my writing, & 117 & 30 & 3.90 \\
\hline 10 & I have what it takes to do well in English writing class. & 68 & 30 & 2.27 \\
\hline
\end{tabular}

The Table shows that with regard to the sixth statement, the students agreed that they could do well in their English writing class. It was affirmed by the results of the observation on the students' active engagement in writing in the inclass activities. However, they disagreed that they were confident about their ability to address the topic (narrative text) on the final exam (Statement 7). Although they thought they could do well in their writing class, they were still not sure with their performance in their final exam. In order to clarify the students' responses toward this statement, an immediate interview was conducted. Furthermore, responses were favorable regarding to the eighth statement. It was found out that the students agreed that peers' editing and teacher's feedback helped them improve their writing. They considered that giving and accepting feedback from their peers were okay. The interview revealed that the students felt positive toward their writing in the in-class activities as they had peer's editing and teacher's feedback. Meanwhile, for the final exam, they would not have any chance to have proof reading and peer editing process.

Meanwhile, students' responses to the ninth statement revealed that they neither agreed nor disagreed that they could easily understand their teacher's instant explanation. For this reason, some students preferred coming to the class without any preparation; for example, without watching the video lectures or reading the materials. For the last statement, the students disagreed that they could do well in English writing class. An immediate interview showed that the students were not actively engaged in their online self-learning activities; that was why they were not fully prepared with the materials. In summary, the students perceived that the flipped classroom model was beneficial for the improvement of their writing competence. They felt that the peers' editing and teacher's feedback helped them improve their writing competence regardless of the fact that they disagreed regarding the importance of video lectures.

\section{DISCUSSIONS}

This study aimed to answer questions on: 1) how students perceive the meaningfulness of writing activities employed in the flipped classroom model, and 2) how students perceive their writing competence after following the flipped classroom model. Each research question is discussed below. 


\section{A. Students' Perception toward the Meaningfulness of Writing Activities Employed in the Flipped Classroom Model}

Students' perception toward a new teaching model applied influences their learning outcomes. Therefore, investigating how they perceive the work they do for their English writing class is crucial. Students' responses to the first and second statements of the questionnaire indicated a positive result. They considered that the activities included in their flipped classes were valuable for them and not a waste of time. This is a good starting point as the students' perception on the usefulness is related to the learning behavior, which in turn influences their learning outcomes (Davis, 1989). In line with this, students agreed that the activities during the writing class improved their understanding of the key concept. Flipped classroom model provides students abundant time for collaborative works (with both the teacher and peers). The students' engagement in collaborative works helps and elevates their writing ability. By being engaged in the activities (i.e. doing, discovering, exploring, and trying out new ideas), students learn and understand more (Clarke, 2008).

Besides, the students' acknowledgment that they preferred just listening to the teacher's instant explanation in class to watching video lectures prior to the class indicated that the teacher must not repeat the explanation given through the online class as well as the video lectures within the in-class activities. As a substitute, the classroom section must be used for checking the students' understanding on their own learning and finishing the tasks.

In short, the results of the studies showed that in general the students perceived that the flipped classroom model was meaningful. However, there were several drawbacks that are worth mentioning. One of the problems was revealed from the students' responses to fourth statements in which not all of the students agreed that viewing video lectures and reading the materials in online self-learning prepared them for the class activity. This was also affirmed by the results of the observation on the students' activeness in online self-learning as well as their responses to an immediate interview asking for their reasons for not watching the video lectures. This finding is contradictory to the reports of some previous studies (Lage, Platt, \& Treglia, 2000; Wang \& Zhang, 2013; Webb, Doman, \& Pusey, 2014) showing that in the end of the implementation, the students prefer watching video lecturer at home as part of their online self-learning.

A possible interpretation for the different results in the students' perception with regard to the use of video lectures, it would be necessary to help students to get accustomed to the online materials given prior to the class. In addition, the students' age might also influence their readiness in attending the flipped classroom model. The previous studies (e.g., Arnold-Garza, 2014; Bishop \& Verleger, 2013; Fulton, 2012; Huba \& Freed, 2000; Ling, 2015; Snowden, 2012) revealed students' more positive perception as they were conducted in the university level. Therefore, it is not so surprising that the students in this study, which are high school students, could not fully participate in the video viewing.

Meanwhile, the result of the immediate interview, which disclosed the students' reasons for not finishing their online activities, is supportive to Nielsen's (2011) in which students can be unmotivated to do homework. The tasks, such as watching videos, were firstly perceived as more homework by the students because they were not used to a new kind of learning environment (Wang \& Zhang, 2013). Besides, the students had so many tasks to complete, not only for the English subject but also other subjects. Hence, prioritization was necessary. It was observed that the students felt that the course workload was excessive; they had to watch some video lectures, read online materials as well as do some quizzes. Therefore, they simply chose doing one or more tasks as a way of cutting back. The rationale behind this was that disregarding one or two tasks would have little impact on their grades. For this reason, there was a small number of the students who preferred having a typical lecture classroom instructions to watching video lectures.

An important finding was that some students felt that classroom lecture is still preferable than the video lectures as it is easier for them to get distracted while watching the video lectures. Therefore, they were unmotivated to watch. Furthermore, the lacking of facilities to support the online self-learning can be inferred that parents seemed to be uninterested in accepting responsibility for flipped class facilities. Even though, ideally, parents, teacher, and students must work together by the mean of technology in order to attain a success in the implementation of the flipped classroom model. We propose the relation as depicted in Figure 1 to show the roles of three components involved in the implementation of the flipped classroom model. 


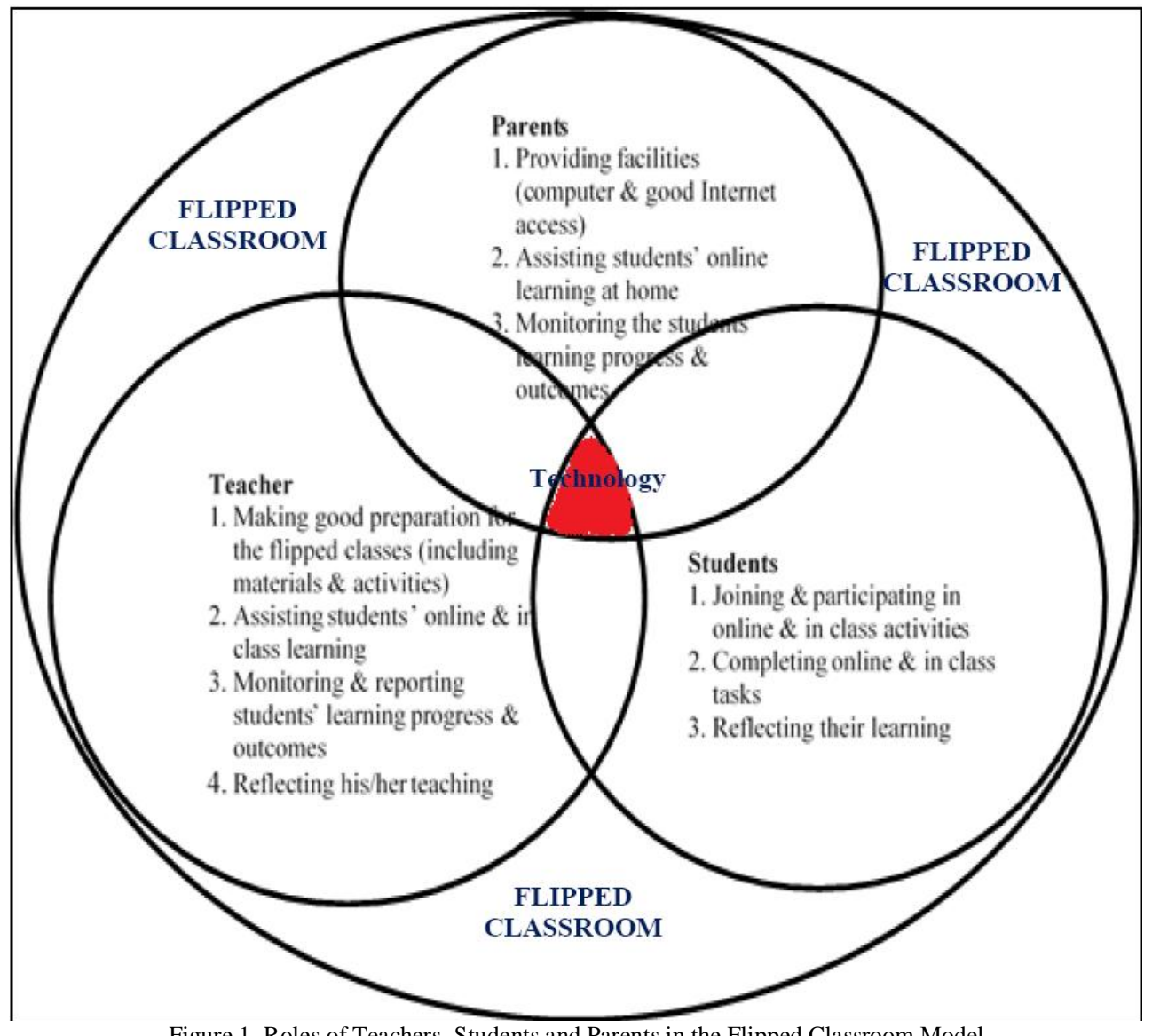

Figure 1. Roles of Teachers, Students and Parents in the Flipped Classroom Model

In general, the students admitted that learning writing using flipped classroom model was meaningful for them. However, better facilities as well as parents' supports are needed in order to have all of the students actively participate in all the outside the classroom activities (watching the video lectures, reading the online materials, and finish the online quizzes). The strong dependence on technology in completing the task (watching video), made some students unable to complete it. Many students in underprivileged communities did not have enough access to technology at home. Besides, teacher must not repeat the explanation given through the online class as well as video lectures within the classroom section, as a substitute, the classroom section must be used for checking the students' understanding on their own learning and finishing the tasks. Therefore, there is an urgency for the students to watch the videos and read the materials prior to the class session.

\section{B. Students' Perception toward the Benefits of Flipped Classroom Model on Their Writing Competence}

Students perceived the flipped classroom model is beneficial for the improvement of their writing competence. They agreed that they could do well in their English writing class. This happens as in flipped classroom model, students are assisted during their three writing stages (pre-, during, and post-writing stages). In the flipped classroom model, students have more time to do activities in the classroom as the lecture has been done through the videos that must be watch prior to the class (Musib, 2014; Roach, 2014). In addition, by having video lectures, teacher's instruction in the class becomes lesser and more communicative activities are created.

Furthermore, the students' positive perception toward the implementation of the flipped classroom model was also proven by their positive response on the eight statements that peers' editing and teacher's feedback helped them to improve their writing. They felt positive in giving and accepting feedback from their peers. This finding positively confirms Grami's (2012) and Vurdien's (2011) work that students showed positive attitudes towards peers' feedback. The students found content related feedback from their teacher and peers helped them to write an appropriate story based on the given topic. On the other hand, they expected to receive feedback on their dictions and grammar; spelling, and sentence structure the most. By having peer checking and editing prior to the along with the writing process, students felt more confidence toward their writing product.

The teacher's as well as peers' feedacback helps during the writing process. However, the feedback made the students less confident about their ability to address the topic (narrative text) on the final exam. As it was stated on their response toward the seventh statement, the students felt unconfident on the final exam as in the exam they would not have any help during the writing stage. Therefore, the teacher must also help students to be able to check their own work and get accustomed to self-editing process prior to submit or publish their work. 
Further important interpretation made was about students' lacking of preparation prior to their in-class activities. Not all of the students came to the class well prepared. They seemed to prefer listening to the teacher's instant explanation within in-class time to watching the video lectures. The first analysis that can be made is that for certain materials, which are considered thoughtful, such as grammatical rules, video lectures as well as online reading; it seems to be more preferable if it is accompanied with a direct explanation. On the other hand, for materials that are considered easy in which students have already owned sufficient prior knowledge, instant explanation is considered adequately clear. As a result, some students preferred just come into the class without any preparation; without watching the videos or reading the materials. Therefore, challenges, such as students' inactive participation in online class and unwillingness to watch the videos prior to the class, must be anticipated. For that reason, Gannod, Burge and Helmick (2007) utter that flipping was a viable option and that both could reap the benefits of flipping.

\section{CONCLUSIONS}

This study has reported the results of investigation on the students' perception toward the implementation of the flipped classroom model. There were two areas that students have to perceive, namely: meaningfulness of the implementation of the flipped classroom model, and the students' perception of their writing competence as the results of the implementation. In general, the students perceived that the implementation of the flipped classroom model was meaningful and they also perceived that their ability in writing improved as the results of the implementation of the flipped classroom model. However, the session in the video lectures viewing should be made more appealing by providing more interesting video materials which are not discussed again in the in-class activities. By doing so it is expected that the students will be involved in their online self-learning more intensively. Apart from the students' positive perception on the two areas of investigation, students' confidence in their abilities in writing is promoted. This is important to encourage them for further learning.

We propose some suggestions for the implementation of the flipped classroom model in the future. First, the teacher must be ready with some preventive actions. Before implementing, the teacher must ensure that all of the students understand the concept of the flipped classroom model and its procedures. Second, the teacher must also get enough support from the school as well as parents. The school must be ready with the facilities. Meanwhile, parents must also be ready with the facilities for the students' online self-learning at home and assist the students' learning difficulties. Finally, in the process of implementing, the teacher must constantly do reflection and revision on the implementation. Meanwhile, after the process of implementing, evaluation must be made in order to have a more successful implementation of the flipped classroom model.

\section{APPENDIX. QUESTIONNAIRE FOR STUDENTS}

\section{PERCEPTION ON THE IMPLEMENTATION OF FLIPPED CLASSROOM MODEL}

This questionnaire aims to know students' perception on the implementation of flipped classroom model. It has two parts: Meaningfulness and Competence.

- Read the statements with responses varying from "strongly agree" (1), "agree" (2), "neither agree nor disagree" (3), "disagree" (4), to "strongly disagree" (5).

- Give your response by putting a tick $(\sqrt{ })$ in the provided space.

\begin{tabular}{|c|c|c|c|c|c|}
\hline Statement & 1 & 2 & 3 & 4 & 5 \\
\hline 1. The work I do for English writing class is valuable to me. & & & & & \\
\hline 2. The work I do in English writing class is a waste of time. & & & & & \\
\hline 3. The activities during the writing class improve my understanding of the key concept. & & & & & \\
\hline 4. Viewing video lectures and read the materials before class prepare me for the class activity. & & & & & \\
\hline $\begin{array}{l}\text { 5. I do not see any significance to view the lecture and read the materials before class, so I do not } \\
\text { although I am supposed to. }\end{array}$ & & & & & \\
\hline
\end{tabular}

\begin{tabular}{|c|c|c|c|c|c|}
\hline Statement & 1 & 2 & 3 & 4 & 5 \\
\hline 6. I can do well in my English writing class. & & & & & \\
\hline 7. I am confident about my ability to address the topic (narr & & & & & \\
\hline 8. Peers' editing and teacher's feedback help me to improve & & & & & \\
\hline 9. I can easily understand my teacher's instant explanation. & & & & & \\
\hline 10. I have what it takes to do well in English writing class. & & & & & \\
\hline
\end{tabular}

(Adapted from Yujing, 2015)

\section{REFERENCES}

[1] Afrilyasanti, R., Cahyono, B., \& Astuti, U. P. (2016). Effect of flipped classroom model on Indonesian EFL students' writing ability across and individual differences in learning. International Journal of English Language and Linguistics Research 4.5, 65-81. 
[2] Agustina, D. S. (2015). The use of "flipping classroom" for teaching storytelling to the tenth graders. Magister Thesis, State University of Surabaya.

[3] Arnold-Garza, S. (2014). The flipped classroom teaching model and its use for information literacy instructions. Communications in Information Literacy 8.1, 7-22.

[4] Bertram, D. (2007). Likert scales. http://poincare.matf.bg.ac.rs/ kristina/topic-dane-likert.pdf (accessed 2/11/2013).

[5] Bishop, J., \& Verleger, M. (2013). The flipped classroom: A survey of the research. Paper presented at the 120th ASEE Annual Conference \& Exposition, Atlanta.

[6] Brinkley, K. (2012). Flipped classrooms. http://tenntlc.utk.edu/2012/04/04/flipped-classrooms/ (accessed 1/12/2015).

[7] Chester, A., Buntine, A., Hammond, K., \& Atkinson, L. (2011). Podcasting in education: Student attitudes, behavior and selfefficacy. Journal of Educational Technology \& Society 14.2, 236-247.

[8] Clarke, A. (2008). E-Learning skills ( $2^{\text {nd }}$ ed). New York. Palgrave Macmillan.

[9] Cole, J. E., \& Kritzer, J. B. (2009). Strategies for success: Teaching an online course. Rural Special Education Quarterly 28.4, 36-40.

[10] Davis, F. D. (1989). Perceived usefulness, perceived ease of use, and user acceptance of information technology. MIS Quarterly 13.3, 319-340.

[11] Demski, J. (2013). 6 Expert tips for flipping the classroom. Campus Technology 26.5, 32-37.

[12] Fulton, K. (2012). Upside down and inside out: flip your classroom to improve student learning. ISTE (International Society for Technology in Education). June/July 2012 Eds, 12-13.

[13] Gannod, G. C., Burge, J. E., \& Helmick, M. T. (2008). Using the inverted classroom to teach software engineering. Proceedings of the $30^{\text {th }}$ international conference on software engineering: Using the inverted classroom to teach software engineering. New York, NY: ACM.

[14] Grami. M. A. (2012). Online collaborative writing for ESL learners using blogs and feedback checklists. English Language Teaching 5.10, 43-48.

[15] Herreid, C., \& Schiller, N. (2013). Case studies and the flipped classroom. Journal of College Science Teaching 42.5, 62-66.

[16] Hill, C. (2013). The benefits of flipping your classroom. http://www.facultyfocus.com/articles/instructional-design/the-benefitsof-flipping-your-classroom/ (accessed 26/8/2014).

[17] Houston, M. L. L. (2012). Humanizing the classroom by flipping the homework versus lecture equation. http://www.tandfonline.com/loi/ncal20\#.VVcKG_mqqko (accessed 1/12/2015).

[18] Huba, M. E., \& Freed, J. E. (2000). Learner-centered assessment on college campuses: Shifting the focus from teaching to learning. Boston: Allyn and Bacon.

[19] Johns, R. (2010). Likert items and scales. Survey Question Bank: Methods Fact Sheet 1. March 2010 Eds, 1-11.

[20] Lage, M.J., Platt, G.J. \& Tregalia, M. (2000). Inverting the classroom: A gateway to creating an inclusive learning environment. Journal of Economic Education 31.1, 30-43.

[21] Ling, J. (2015). Application of flipped classroom in VB program design experiment teaching. Paper presented at the $3^{\text {rd }}$ International Conference on Management, Education, Information and Control.

[22] Murtiyasa, W., Esti, F., \& Ulfa, N. F. (2015). Implementation of flipped classroom strategy in mathematics learning to students' cognitive skill. Proceeding of International Conference on Research, Implementation and Education of Mathematics And Sciences 2015, Yogyakarta State University, 17-19 May 2015.

[23] Musib, M. K. (2014). Student perceptions of the impact of using the flipped classroom approach for an introductory-level multidisciplinary module. CDTL Brief 17.2, 15-20.

[24] Nielsen, L. (2011). Five reasons I'm not flipping over the flipped classroom. http://www.techlearning.com/default.aspx?tabid=100\&entryid=3360 (accessed 1/12/2015).

[25] Overmeyer, J. (2012). Flipped classrooms 101. www.naesp.org/SeptOct12. September/October Eds. 46-47 (accessed $1 / 12 / 2015)$

[26] Restad, P. (2013). "I don't like this one little bit" tales from a flipped classroom. http://www.facultyfocus.com/articles/teaching-with-technology-articles/i-dont-like-this-one-little-bit-tales-from-a-flippedclassroom/ (accessed 1/12/2015)

[27] Roach, T. (2014). Students' perceptions toward flipped learning: New methods to increase interaction and active learning in economics. International Review of Economics Education 17.1, 74-84.

[28] Ruddick, K. W. (2012). Improving chemical education from high school to college using a more hands-on approach. Doctoral Dissertation, University of Memphis.

[29] Slezak, S. (2014). Flipping a class: The learning by doing method. Paper presented at 2014 Spring ConfChem: Flipped Classroom.

[30] Snowden, K. E. (2012). Teacher perceptions of the flipped classroom: Using video lectures online to replace traditional in-class lectures. Texas: University of North Texas.

[31] Sung, K. (2015). A case study on a flipped classroom in an EFL content course. Multimedia-Assisted Language Learning 18.2, 159-187.

[32] Syafitri, W. (2014a). Flipped class for more effective and efficient English class in Indonesian EFL context. Paper resented at the $6^{\text {th }}$ National Engish Language Teachers and Lecturers (NELTAL) Conference, State University of Malang, March 29, 2014.

[33] Syafitri, W. (2014b). The impact of flipped classroom on reading comprehension of high school students with different cognitive learning styles. Magister Thesis, State University of Malang.

[34] Vagias, W. M. (2006). Likert-type scale response anchors. Clemson International Institute for Tourism \& Research Development, Department of Parks, Recreation and Tourism Management, Clemson University.

[35] Vurdien, Ruby. (2011). Enhancing writing skills through blogging in an advanced English as a Foreign Language class in Spain Computer Assisted Language Learning 26.2, 126-143.

[36] Wang, X. D., \& Zhang, C. J. Z. (2013). The application research of flipped classroom in university teaching - A case study on professional English of educational technology. Modern Educational Technology 8.1, 11-16. 
[37] Webb, M., Pussey, E., \& Doman, K. (2014). Flipping a Chinese university EFL course: What students and teachers think of the model. The Journal of Asia TEFL 11.4, 53-87.

[38] Yujing, N. (2015). Influence of flipped classroom on learner's empowerment-a study based on English writing courses in China. Journal of Literature, Languages and Linguistics 12.1, 1-7.

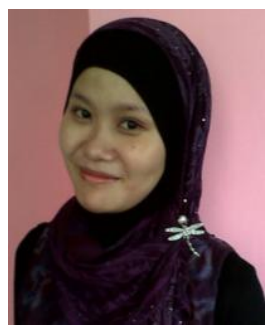

Rida Afrilyasanti is an EFL teacher in Sekolah Menengah Atas (senior high school) Negeri 8 Malang, East Java, Indonesia. She earned her Master and Undergraduate degree from the English Language Teaching Program, State University of Malang in 2009. During her undergraduate education, she participated in undergraduate students exchange program in the U.S.A. (Global UGRAD) in 2008. She was also joining summer language class through theatre, hosted by the California Institute of English Language and Theatre, HSU (Humboldt State University) cooperating with the Prague School of Language. In 2011, she won paper presentation conducted by Pearson and was invited to join Amazing Mind Teacher Conference in Da Nang, Vietnam. One of her books titled "Digital Storytelling as an Alternative Learning Media for EFL Learners" was published and sold internationally at amazon.com. Besides, she is active in a social work with Indonesians Hope (www.IndonesiansHope.wordpress.com). She managed some social projects dealing with orphaned kids, namely: get orphaned kids to read in English project, mini library project, life skill training project, etc. In 2012 she was assigned to participate in "Project Design and Proposal Writing Training-IDEP- SPRING 2012" (http://courses.worldlearning.org/.) In short, she can be contacted via email: rida.afrilyasanti@yahoo.com.

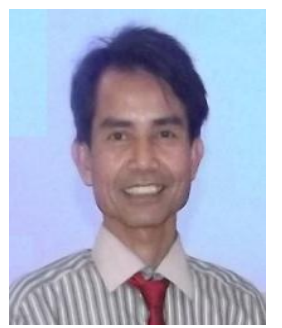

Bambang Yudi Cahyono is a Professor in Applied Linguistics at Universitas Negeri Malang, East Java, Indonesia. He gained his Master of Arts in Applied Linguistics from Concordia University, Montreal, Canada (2000) and Ph.D. from the Department of Linguistics and Applied Linguistics of the University of Melbourne, Australia (2006)..He participated in the summer school on "Writing in the Classroom" in the English Language Institute of the University of Surrey, Guildford, United Kingdom (1995); "American Studies for Language Teachers" at the University of Chicago at Illinois, USA (2001); and online-course on "The Teaching of Critical Thinking Skills" managed by the University of Oregon, Eugene, USA (2006). E-mail: yudic2000@yahoo.com

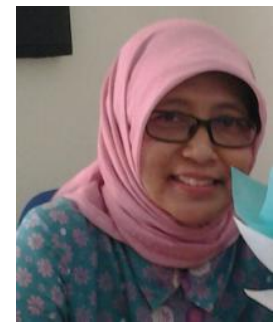

Utari Praba Astuti is a lecturer in English Language Teaching (ELT) at Universitas Negeri Malang, East Java, Indonesia. She gained her master degree (M.A) of Primary Education from the University of London, UK (1997). She joined the postgraduate program at Universitas Negeri Malang and gained her doctorate degree (Dr.) in 2013. Before taking her master degree in UK, she took part in a Summer Course, 'Culture in ELT' held in Lancaster, UK (1995). She was elected as the coordinator of the program organized by Decentralized Basic Education (DBE2-USAID) focusing on 'Active-Learning in the Science and Language Classes' (2006-2008). By the end of the program, she was invited by Pittsburgh University, Pennsylvania to sit in classes and acquire the ideas and best practices of active learning especially in the Science and Language classes. Now, she is handling the Culture and Language Center of the University to provide some services dealing with some test preparations such as IELTS and TOEFL, and general Indonesian (for foreigners), English, Germany as well as Arabic. Her e-mail address is utari_pastuti@yahoo.com 